\title{
PHYTOCHEMICAL AND PHARMACOLOGICAL EVALUATION OF A MEDICINAL PLANT OF INDONESIAN TENGGER ETHNIC GROUP
}

\author{
A.S. Nugraha ${ }^{1,2, 凶}$, I.D. Anggita ${ }^{2}$, A.A.I. Ratnadewi ${ }^{2}$, T.A. Siswoyo ${ }^{2}$, \\ A.N.W. Pratama ${ }^{1}$, R. Hendra ${ }^{3}$ and P.A. Keller ${ }^{4}$ \\ ${ }^{1}$ Drug Utilisation and Discovery Research Group, Faculty of Pharmacy, University of Jember, \\ Jember, 68121, Indonesia. \\ ${ }^{2}$ Graduate School of Biotechnology, PUI-BioTIn, University of Jember, Jember, 68121 \\ Indonesia \\ ${ }^{3}$ Department of Chemistry, Faculty of Mathematics and Natural Sciences, University of Riau, \\ Riau, Indonesia \\ ${ }^{4}$ School of Chemistry \& Molecular Bioscience and Molecular Horizons, University of \\ Wollongong, and Illawarra Health \& Medical Research Institute, Wollongong, NSW 2522, \\ Australia \\ ${ }^{\boxplus}$ Corresponding Author: arisatia@unej.ac.id
}

\begin{abstract}
The people of Tengger, the last Hindu Society on the Javanese Island-Indonesia, use leaves from Cordyline fruticosa to treat different ailments related to blood circulation problems and high blood sugar levels. However, there are limited studies on the medicinal potency of the plant. In this study, the crude methanol extract was chemically profiled using a vanillin staining agent, then fractionated, and subjected to exhaustive preparative HPLC separation, which isolated the major components. Antioxidant and $\alpha$-amylase inhibition bioassays were performed to evaluate the plant potency as an antidiabetic medicament. Chemical profiling indicated phenolic compounds present with the major constituent identified as rutinoside based on NMR and MS spectral data analysis. The crude methanol extract indicated DPPH scavenging activity with an $\mathrm{IC}_{50}$ value of $116.65 \pm 2.60 \mu \mathrm{g} / \mathrm{mL}$. The extract exhibited a moderate $\alpha$-amylase inhibition with an $\mathrm{IC}_{50}$ value of $352.42 \pm 2.76 \mu \mathrm{g} / \mathrm{mL}$. Overall, this study reports the phytochemical and pharmacological evaluations of Cordyline fruticosa for the first time.

Keywords: Tengger, Sawang, Cordyline fruticose, HPLC, Rapid Isolation, Antioxidant, Antidiabetic
\end{abstract}

RASĀYAN J. Chem., Vol. 14, No.4, 2021

\section{INTRODUCTION}

The people of Tengger are located in the Bromo Mountain range region and are one of the few communities still practicing Hinduism in the Islam majority population of Indonesia. This society is rich in cultural values, including its traditional medicine, passed down throughout the generations. Locally named as "sawang," Cordyline fruticosa (L.) A.Chev has been domesticated by the Indigenous people of Tengger as a traditional medicine to treat diarrhea, dysentery and to reduce blood sugar levels. The shrub is also used as house ornaments enabling facile access for medicinal use.

There are limited reports on the C. fruticosa species, including isolation studies from the Cameroonian $C$. fruticosa leaves, which produced steroidal constituents, namely fruticoside $\mathrm{H}$, fruticoside I and fruticoside J. ${ }^{1}$ The aerial component of this Agavaceae plant produced a sulfated steroidal derivative (fruticogenin A) and steroidal saponins, fruticoside $\mathrm{K}$, fruticoside $\mathrm{L}$ and fruticoside $\mathrm{M}^{2}$ Bioactivity evaluation on fruticoside $\mathrm{K}$ and $\mathrm{M}$ revealed cytotoxicity against melanoma A375, breast adenocarcinoma MDA-MB-231, and colon carcinoma HCT116 cell lines with $\mathrm{IC}_{50}$ values ranging from $21.52-86.21 \mu \mathrm{M}$. These are weakly active when compared to the cisplatin standard, which show $\mathrm{IC}_{50}$ values ranging from $0.54-6.45 \mu \mathrm{M} .^{2}$ In addition, fruticoside $\mathrm{H}$ and I possessed modest cytotoxic activity against human colon carcinoma HCT 116, human breast adenocarcinoma MDA-MB 231, and human malignant melanoma cell lines A375 with $\mathrm{IC}_{50}$ values ranging from $37.83-69.68 \mu \mathrm{M} .^{1}$

Rasayan J. Chem., 14(4), 2516-2520(2021)

http://dx.doi.org/10.31788/RJC.2021.1446499

This work is licensed under a CC BY 4.0 license. 
RASĀYAN $J$. Chem.

Vol. 14 | No. 4 |2516-2520| October- December | 2021

In this current study, the phytochemistry investigation of $C$. fruticose isolated flavonoids and the antidiabetic and antioxidant activities evaluation were reported for the first time.

\section{EXPERIMENTAL}

\section{Materials and Instrumentation}

The leaves of $C$. fruticosa were collected from Tosari Village (Pasuruan District, East Java, Indonesia) by Ms Galuh Sukmawati, who identified and supplied the material. Sample vouchers were stored in the Drug Utilisation and Discovery Research Group, University of Jember, Indonesia, under accession CF2019. All chemicals used in the secondary metabolite isolation, antioxidant and antidiabetic bioassays were purchased from Merk.

Secondary metabolite profiling was performed using analytical High-Pressure Liquid Chromatography (HPLC) using a Shimadzu Prominence-I LC-2030C-3D PDA system controlled by LabSolutions LC Workstation Ver.5.73 with a symmetry $\mathrm{C}_{18}$ column $(5 \mu \mathrm{m}, 100 \AA$, $4.6 \times 150 \mathrm{~mm})$. Secondary metabolite isolation was conducted using a Shimadzu Binary Preparative HPLC consisting of a preparative pump LC20AP, a system controller CBM-20A, a preparative auto-sampler SIL-10AP and a UV-Vis detector SPDM20A using similar software. A preparative column (Luna $\mathrm{C}_{18}$ column, $5 \mu \mathrm{m}, 100 \AA, 19 \mathrm{x} 150 \mathrm{~mm}$ ) with a protective $\mathrm{C}_{18}$ guard $(5 \mu \mathrm{m}, 100 \AA, 19 \times 10 \mathrm{~mm})$ was employed. 1D and 2D-Nuclear Magnetic Resonance (NMR) spectra $\left({ }^{1} \mathrm{H}\right.$ and ${ }^{13} \mathrm{C}$ NMR, Correlated Spectroscopy (gCOSY), Heteronuclear Single Quantum Coherence (gHSQC), Heteronuclear Multiple Bond Correlation (gHMBC), Total Correlation Spectroscopy (zTOCSY)) were obtained a Bruker Avance $500 \mathrm{MHz}$ at 500 and $125 \mathrm{MHz}$. Electrospray Ionisation Mass Spectrometry (ESIMS) spectra were generated from a Shimadzu LC-2010 mass spectrometer in positive and negative modes.

\section{Extraction, Isolation and Molecular Characterization}

The dried powdered sample $(75.00 \mathrm{~g})$ was soaked in methanol $(1.5 \mathrm{~L})$ followed by stirring for $24 \mathrm{~h}$. The resulting filtrate was concentrated to produce a brown solid $(7.40 \mathrm{~g})$. The less polar components were removed by liquid-liquid partition using hexane followed by dichloromethane ( 5 x $25 \mathrm{~mL})$. The remaining dichloromethane layer was re-extracted with ethyl acetate $(5 \times 50 \mathrm{~mL})$ to produce a flavonoid-rich fraction $(0.93 \mathrm{~g})$. The extract was mixed with methanol: water $(1: 1,50 \mathrm{~mL})$ using sonication $(30 \mathrm{~min})$. The solution was loaded into a short $\mathrm{C}_{18}$ column $(1.5 \times 2 \mathrm{~cm})$ with pressure assistance to produce a $50 \mathrm{~mL}$ fraction. The supernatant was filtered $(0.45 \mu \mathrm{m})$ and loaded onto preparative HPLC column $(19 \times 150 \mathrm{~m}, 5 \mu \mathrm{m})$ in 10 injection blocks with a gradient flow from $0-40 \%$ acetonitrile in water within 2 minutes, to a gradient flow from $40-100 \%$ acetonitrile in water within 18 minutes, isocratic development at $100 \%$ acetonitrile for 5 minutes before returning the system to $0 \%$ acetonitrile in water at 30 minutes. The flavonoid constituent, quercetin, was collected at $t_{\mathrm{R}} 18.5$ minutes.

\section{Quercetin-O-3-rutinoside (1)}

Yellow solid (31.1 mg, $1.54 \mathrm{mg} / \mathrm{g}$ dried plant sample); ${ }^{1} \mathrm{H}-\mathrm{NMR}$ (methanol- $\left.d_{6}, 500 \mathrm{MHz}\right), 7.67$ (s, $1 \mathrm{H}, \mathrm{H} 2^{\prime}$ ), $7.62\left(\mathrm{~d},{ }^{3} J=8.5 \mathrm{~Hz}, 1 \mathrm{H}, \mathrm{H6} 6^{\prime}\right), 6.88\left(\mathrm{~d},{ }^{3} J=8.5 \mathrm{~Hz}, 1 \mathrm{H}, \mathrm{H} 5^{\prime}\right), 6.40\left(\mathrm{~d},{ }^{4} J=2.0 \mathrm{~Hz}, 1 \mathrm{H}, \mathrm{H} 8\right), 6.21\left(\mathrm{~d},{ }^{4} J=\right.$ $2.0 \mathrm{~Hz}, 1 \mathrm{H}, \mathrm{H6}), 5.10\left(\mathrm{~d},{ }^{3} J=7.5 \mathrm{~Hz}, 1 \mathrm{H}, \mathrm{H} 1^{\prime \prime}\right), 4.52\left(\mathrm{~s},{ }^{3} J \leq 1 \mathrm{~Hz}, 1 \mathrm{H}, \mathrm{H} 1^{\prime \prime \prime}\right), 3.80\left(\mathrm{dd},{ }^{3} J=10.9,{ }^{3} J=8.5\right.$ $\left.\mathrm{Hz}, 1 \mathrm{H}, \mathrm{H} 6 \mathrm{~B}^{\prime \prime}\right), 3.64$ (m, 1H, H2"'), 3.54 (m, 1H, H3'"'), 3.48 (m, 1H, H2"), 3.45 (m, 1H, H5"'), 3.42 (m, $\left.1 \mathrm{H}, \mathrm{H}^{\prime \prime}\right), 3.39\left(\mathrm{dd},{ }^{2} J=10.9,{ }^{3} J=8.5 \mathrm{~Hz}, 1 \mathrm{H}, \mathrm{H} 6 \mathrm{~A}^{\prime \prime}\right), 3.33$ (m, 1H, H5"), 3.27 (m, 1H, H4"), 3.27 (m, 1H, $\left.\mathrm{H} 4^{\prime \prime \prime}\right), 1.12$ (d, $\left.{ }^{3} \mathrm{~J}=6.5 \mathrm{~Hz}, 3 \mathrm{H}, \mathrm{H6}^{\prime \prime \prime}\right) ;{ }^{13} \mathrm{C}-\mathrm{NMR}$ (CD $\left.\mathrm{CD}_{3} \mathrm{OD}, 125 \mathrm{MHz}\right), 179.4$ (C4), 166.0 (C7), 162.9 (C5), 159.3 (C2), 158.5 (C9), 149.8 (C4'), 145.8 (C3'), 135.6 (C3), $123.6\left(\mathrm{C}^{\prime}\right), 123.1\left(\mathrm{C}^{\prime}\right), 117.7\left(\mathrm{C} 2^{\prime}\right), 116.0$ (C5'), $105.6(\mathrm{C} 10), 104.7\left(\mathrm{Cl}^{\prime \prime}\right), 102.6$ (C1"'), 99.9 (C-6), 94.7 (C8), 78.1 (C5"), 77.2 (C3"), 75.7 (C2"), 73.9 (C4"'), 72.2 (C3"'), $72.1\left(\right.$ C2 $\left.^{\prime \prime \prime}\right), 71.4\left(\right.$ C4" $\left.^{\prime \prime}\right), 69.7$ (C5'"'), 68.5 (C6"), 17.9 (C6"'); ESMS: $611(\mathrm{M}+\mathrm{H})^{+}$ and $609(\mathrm{M}+\mathrm{H})^{-}$.

\section{2,2-diphenyl-1-picrylhydrazyl (DPPH) Scavenging}

This was performed based on a protocol reported by Soler-Rivas et al. (2000). ${ }^{3}$ A concentration series of methanol extracts were prepared $(0,1,2,4,6,8,10$, and $15 \mu \mathrm{g}$ GAE/mL (GAE: Gallic Acid Equivalent)). To the methanol extract $(2000 \mu \mathrm{L})$, DPPH reagent $(90 \mu \mathrm{M}, 1000 \mu \mathrm{L})$ was added, followed by incubation 
for 30 minutes in the absence of light. Absorbance was recorded at $\lambda 515 \mathrm{~nm}$ with the percent inhibition evaluated based on Equation 1, in which $\mathrm{A}^{0}$ is the control slope, and $\mathrm{A} 1$ is the sample slope.

$\%$ Inhibition $\left.=\left(\left[\mathrm{A}^{0}-\mathrm{A}^{1}\right]\right) / \mathrm{A}^{0}\right) \times 100 \%$

\section{$\alpha$-Amylase Inhibition}

The inhibition was profiled based on a standard protocol reported by Hasyim et al. ${ }^{4}$ The crude extract was prepared in a series of concentrations $(0,50,100,200$ and $400 \mu \mathrm{g} / \mathrm{mL})$. Crude extracts $(100 \mu \mathrm{L})$ were added into tubes and labeled as $\mathrm{S}^{+}$and $\mathrm{S}^{-}$. Dimethyl sulfoxide (DMSO) (30\% in phosphate buffer $0.02 \mathrm{M}, \mathrm{pH} 6.9$, $100 \mu \mathrm{L})$ were labeled as $\mathrm{C}^{+}$and C-. Enzyme $\alpha$-amylase $(0.2 \mathrm{U} / \mathrm{mL}$ in phosphate buffer, pH $6.9,150 \mu \mathrm{L})$ was added into $\mathrm{S}^{+}, \mathrm{S}^{-}, \mathrm{C}^{+}$and $\mathrm{C}^{-}$followed by incubation for 15 minutes at $37{ }^{\circ} \mathrm{C}$. Soluble starch $(1 \% \mathrm{w} / \mathrm{v}$, $250 \mu \mathrm{L}$ ) was loaded into each tube followed by further incubation for 15 minutes before the reaction was quenched by boiling for 1 minute. A portion of the mixture $(160 \mu \mathrm{L})$ was added into tubes and was labeled with a similar code before 3,5-dinitrosalicylic acid (DNS) $(80 \mu \mathrm{L})$ was added and the mixture boiled for 5 minutes. The solutions were diluted with distilled water $(720 \mu \mathrm{L})$ followed by absorbance measurement at $540 \mathrm{~nm}$. Acarbose was used as a positive control (standard drug). Percent inhibition was calculated based on Equation 2 below $\left(\mathrm{C}^{+}\right.$: is the control with the enzyme, $\mathrm{C}^{-}$: is the control without enzyme, $\mathrm{S}+$ : sample with enzyme, $\mathrm{S}^{-}$: is a sample without enzyme). $\mathrm{IC}_{50}$ values were calculated as the concentration.

$\%$ inhibition $=\left(\left(\mathrm{C}^{+}-\mathrm{C}^{-}\right)-\left(\mathrm{S}^{+}-\mathrm{S}^{-}\right)\right) /\left(\left(\mathrm{C}^{+}-\mathrm{C}^{-}\right)\right) \times 100 \%$

\section{$\alpha$-Glucosidase Inhibition}

This experiment was based on the bioassay method reported by Zhang et al. with modification. ${ }^{5}$ In a well was placed DMSO $(10 \mu \mathrm{L})$, phosphate buffer $(\mathrm{pH} 7,65 \mu \mathrm{L})$ and 4-nitrophenyl- $\beta$-D-glucopyranoside $(p$ NPG) $(25 \mu \mathrm{L})$ and labeled as B0; In a separate well was placed DMSO $(10 \mu \mathrm{L})$, phosphate buffer $(\mathrm{pH} 7$, $40 \mu \mathrm{L})$, 4-nitrophenyl- $\beta$-D-glucopyranoside ( $p$-NPG) $(20 \mathrm{mM}, 25 \mu \mathrm{L})$ and $\alpha$-glucosidase $(0.2 \mathrm{U} / \mathrm{mL}, 25$ $\mu \mathrm{L}$ ) and labeled as $\mathrm{B}^{1}$. To a well, sample extract (series concentration $1000-31.25 \mu \mathrm{g} / \mathrm{mL}$ in DMSO, 10 $\mu \mathrm{L}), p$-NPG $(20 \mathrm{mM}, 25 \mu \mathrm{L})$ and phosphate buffer $(\mathrm{pH} 7,65 \mu \mathrm{L})$ were loaded and labelled as $\mathrm{S}^{0}$; another well was loaded with sample extract (series concentration 1000-31.25 $\mu \mathrm{g} / \mathrm{mL}$ in DMSO, $10 \mu \mathrm{L}$ ), phosphate buffer $(\mathrm{pH} 7,40 \mu \mathrm{L}), p$-NPG $(20 \mathrm{mM}, 25 \mu \mathrm{L})$ and $\alpha$-glucosidase $(0.2 \mathrm{U} / \mathrm{mL}, 25 \mu \mathrm{L})$ were loaded and labelled as $\mathrm{S}^{1}$. The 96 -well microplate was incubated at $37^{\circ} \mathrm{C}$ for 30 minutes. The reaction was quenched with the addition of $\mathrm{Na}_{2} \mathrm{CO}_{3}$ solution $(0.1 \mathrm{M}, 100 \mu \mathrm{L})$ followed by absorbance measurement at $\lambda 405 \mathrm{~nm}$. $\mathrm{IC}_{50}$ values were calculated as the concentration.

$\%$ Inhibition $=\left(\left(\mathrm{B}^{1}-\mathrm{B}^{0}\right)-\left(\mathrm{S}^{1}-\mathrm{S}^{0}\right)\right) /\left(\left(\mathrm{B}^{1}-\mathrm{B}^{0}\right)\right) \times 100$

\section{RESULTS AND DISCUSSION}

The leaves were initially cleaned and air-dried prior to grinding to produce a dried powder to promote efficient extraction. As previous reports focused on the less polar components ${ }^{1}$, in this study, the less polar constituents (fatty acids and steroids) were removed using hexane and dichloromethane by liquid-liquid partition. The remaining fraction was further partitioned with ethyl acetate to provide the semi-polar components, including phenolics and flavonoid secondary metabolites. The fraction was filtered through a short $\mathrm{RP} \mathrm{C}_{18}$ cartridge followed by filtration with $0.45 \mu \mathrm{m}$ HPLC filter prior to analytical HPLC separation using an optimized method of $40 \%$ to $100 \%$ solvent A within 18 minutes followed by isocratic development for 5 minutes (solvent A $0.1 \%$ trifluoroacetic acid (TFA) in $\mathrm{H}_{2} \mathrm{O}$ and solvent B $0.1 \%$ trifluoroacetic acid in acetonitrile). Further separation was conducted using a semi-preparative HPLC, which successfully isolated the major component at $t_{R} 18.5$ minutes. Analysis of the ${ }^{1} \mathrm{H}$ and ${ }^{13} \mathrm{C}$ NMR spectra (Fig.-1) enabled identification of quercetin-O-3-rutinoside (Fig.-2) along with comparative data with that reported. ${ }^{6}$

Antioxidant and antidiabetic bioactivity studies on the crude extract (Table-1) show the methanol extract of $C$. fruticosa possessed higher superoxide scavenging activity than the standard natural antioxidant, vitamin C. Superoxide is the leading cause of oxidative stress in which the anion can generate highly reactive hydroxyl radicals. This process leads to lipid peroxidation of polyunsaturated fatty acid, which is 


\section{RASĀYAN J. Chem.}

Vol. 14 | No. 4 |2516-2520| October- December | 2021

related to cell stability. ${ }^{7}$ Cell stress prevention through exogenic antioxidant supplements is necessary to recover from metabolic or degenerative diseases. ${ }^{8,9}$
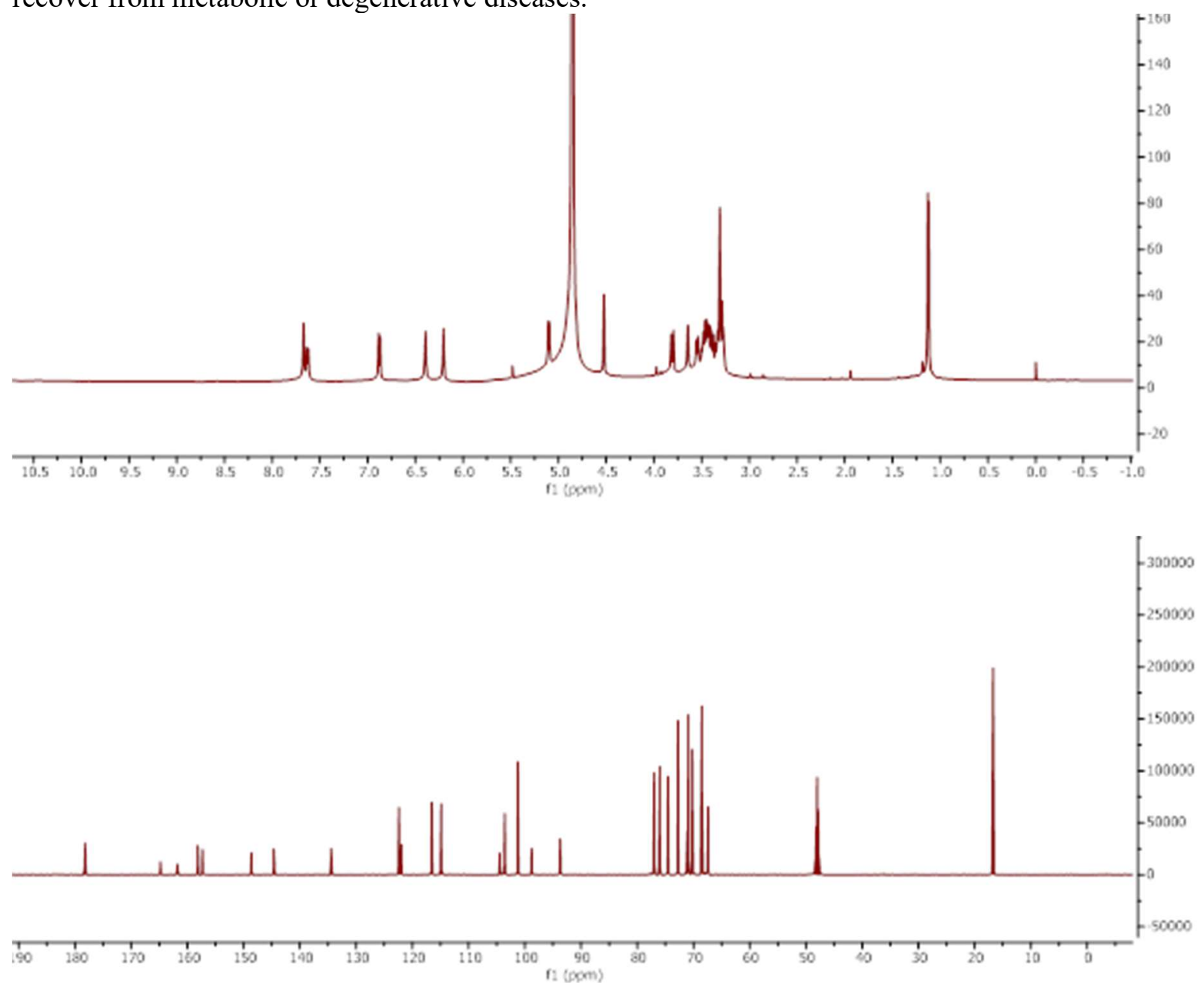

Fig.-1: ${ }^{1} \mathrm{H}-\mathrm{NMR}$ Spectrum (top) and ${ }^{13} \mathrm{C}-\mathrm{NMR}$ Spectrum (bottom) of quercetin-O-3-rutinoside isolated from $C$. fruticose

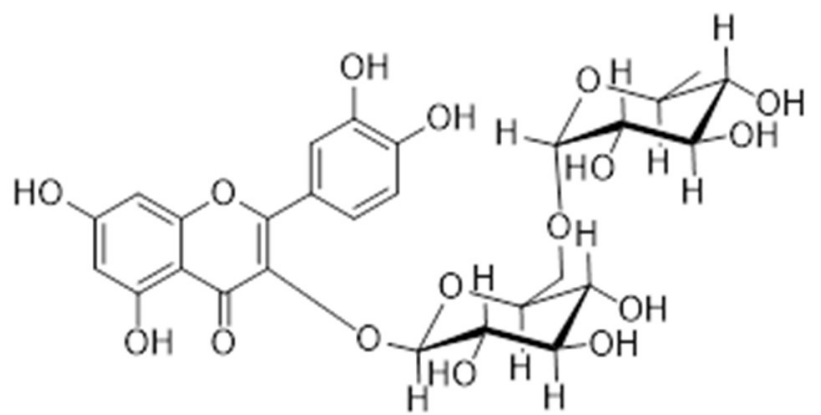

Fig.-2: Quercetin-O-3-rutinoside from the leaves of $C$. fruticosa.

Table-1: Antioxidant and Antidiabetic Activities of Crude Extract

\begin{tabular}{l|l|c|c}
\hline \multicolumn{1}{c|}{ Entry } & IC $_{\mathbf{5 0}}, \boldsymbol{\mu g} / \mathbf{m L}$ & \multicolumn{2}{c}{} \\
\hline & Antioxidant DPPH & $\alpha$-Amylase inhibition & $\alpha$-glucosidase inhibition \\
\hline Methanol extract & $116.65 \pm 2.60$ & $352.42 \pm 2.76$ & $368.91 \pm 19.10$ \\
\hline Acarbose & - & $17.36 \pm 0.33$ & $0.98 \pm 0.02$ \\
\hline Ascorbic acid & $110.75 \pm 2.04$ & - & - \\
\hline
\end{tabular}


RASĀYAN J.Chem.

Vol. 14 | No. 4 |2516-2520| October- December | 2021

Although there is no report regarding the antioxidant and antidiabetic activity of constituents of C. fruticose, previous studies reported the detection or isolation of rutin from other species across different families. ${ }^{5,10,11}$ Therefore, this glycosidic flavonoid has been evaluated for several bioactivities, including as an antioxidant and antidiabetic agent. In silico screening protocols from natural compound, libraries have produced potential lead antidiabetic compounds, including rutin shown by in vitro and in vivo activities. ${ }^{12}$ Rutin was able to reduce glucose concentration 7.2 fold at $4.0 \mathrm{mg} / \mathrm{kg}$.B.wt dosage in male C57BL/6 mice. ${ }^{12}$

\section{CONCLUSION}

The crude methanol extract demonstrated a significant DPPH scavenging activity and a moderate $\alpha$-amylase inhibition, in which spectral data analysis followed by literature comparison showed that the phenolic compound quercetin-O-3-rutinoside, isolated for the first time from $C$. fruticosa.

\section{ACKNOWLEDGEMENT}

ASN thanks Ms. Galuh Sukmawati for supplying the plant sample.

\section{REFERENCES}

1. R.T. Fouedjou, B. Teponno, L. Quassinti, M. Bramucci, D. Petrelli, L.A. Vitali, D. Fiorini, L.A. $\begin{array}{lllll}\text { Tapondjou, L. Barboni, } & \text { Phytochemistry }\end{array}$ https://doi.org/10.1016/j.phytol.2013.10.001

2. B.K. Ponou, R.B. Teponno, A.L. Tapondjou, M.A. Lacaille-dubois, L. Quassinti, M. Bramucci, L. Barboni, Fitoterapia, 134, 454(2019), https://doi.org/10.1016/j.fitote.2019.03.019

3. C. Soler-Rivas, J.C. Esp1'n, H.J. Wichers, Phytochemical Analysis, 11, 330(2000), https://doi.org/10.1002/1099-1565(200009/10)11:5\%3C330::AID-PCA534\%3E3.0.CO;2-G

4. A. Hashim, M.S. Khan, M.S. Khan, M.H. Baig, S. Ahmad, BioMed Research International, 2013, 1 (2013), https://doi.org/10.1155/2013/729393

5. L. Zhang, Z. Tu, T. Yuan, H. Wang, X. Xie, Z. Fu, Food Chemistry, 208, 61(2016), https://doi.org/10.1016/j.foodchem.2016.03.079

6. S. Al-Majmaie, L. Nahar, G.P. Sharples, K. Wadi, S.D. Sarker, Record of Natural Products, 13, 64(2019), http://doi.org/10.25135/rnp.74.18.03.250

7. A.A.I. Ratnadewi, L.D. Wahyudi, J. Rochman, Susilowati, A.S. Nugraha, T.A. Siswoyo, Arabian Journal of Chemistry, 13, 1831(2020), https://doi.org/10.1016/j.arabjc.2018.01.017

8. R. Ramadhan, P. Phuwapraisirisan, I.W. Kusuma and R. Amirta, Rasayan Journal of Chemisrtry, 13(3), 1727(2020), http://dx.doi.org/10.31788/RJC.2020.1335559

9. A.S. Nugraha, A.E.N. Permatasari, C.P. Kadarwenny, D.K. Pratoko, B. Triatmoko, V.A. Rosyidi, I. Norcahyanti, I.P. Dewi, D. Dianasari, I.P. Sary, P. Wangchuk, Journal of Herbs, Spices \& Medicinal Plants, 26, 303(2020), https://doi.org/10.1080/10496475.2020.1734136

10.M. Mutakin, T. Juwita, S. Megantara, I. M. Puspitasari and J. Levita, Rasayan Journal of Chemisrtry, 13, 1379(2020), http://dx.doi.org/10.31788/RJC.2020.1335723

11.S. Megantara, M. Mutakin, E. Halimah, E. Febrina, and J. Levita, Rasayan Journal of Chemisrtry, 13, 1321(2020), http://dx.doi.org/10.31788/RJC.2020.1335766

12.J. Riyaphan, C.H. Jhong, S.R. Lin, C.H. Chang, M.J. Tsai, D.N. Lee, P.J. Sung, M.K. Leong, C.F. Weng, Molecules, 23, 2260(2018), https://doi.org/10.3390/molecules23092260

[RJC-6499/2021] 